\title{
Determination of the Nutritional Composition of Arepa with Egg
}

\author{
Diofanor Acevedo Correa $^{\# 1}$, Piedad M. Montero Castillo ${ }^{\# 2}$, Raúl J. Martelo ${ }^{* 3}$ \\ \# Faculty of Engineering, Food Engineering program, Research Group NUSCA, University of Cartagena \\ Av. El Consulado, St. 30 No. 48-152. Cartagena de Indias, Colombia. \\ * Faculty of Engineering, Research Group in Communications and Informatics Technologies GIMATICA. \\ University of Cartagena \\ 11diofanor3000@gmail.com, ${ }^{2}$ pmargaritamontero@hotmail.com, ${ }^{3}$ rmartelog@gmail.com.
}

\begin{abstract}
The objective of this research was to determinate the nutritional composition of the arepa with egg. For this purpose, corn arepas were made in a concave form. Then, arepas were fried at atmospheric and vacuum pressure at a fixed temperature of $170^{\circ} \mathrm{C}$ and $180^{\circ} \mathrm{C}$ for $300 \mathrm{~s}$ and $400 \mathrm{~s}$, respectively. Proximal analysis, minerals and vitamins were also performed and finally the nutrition label of the arepa was designed. Arepas with lower fat content were obtained during vacuum frying and the mineral content was not affected by the type of frying. The calorie intake is approximately 560 calories, with $66 \%$ calories from fat.
\end{abstract}

\section{INTRODUCTION}

Nutritional research and the food industry depend on accurate public health nutrition information. Mixed dishes or multiingredient foods represent the majority of items in diets worldwide. A true retention should give the proportion of a certain nutrient originally present in the food before frying. Direct measurement of true retention factors therefore requires data on the weight of foods before and after frying or cooking, as well as nutrient content per gram in the raw and fried food. Frying causes dehydration in the food, and therefore the nutrient density in fried foods is higher than in raw products [1].

Food risks are unique and consumers face them every day. However, research often focuses on consumer perception of the risks identified by experts, indicating that consumers overestimate them and pose some dangers and underestimate others. Modern food systems have been described as highly institutionalized, unpredictable, fragmented and contradictory [2]. It emphasizes the importance of providing consumers with information to make informed food choices, presumably in part to mitigate food risks. Labels are an important information tool for consumers as they help to quickly communicate information about the product or production process [3].

In modern food systems, food labelling plays a key role in facilitating the exchange of information between consumers and the food system. It is therefore essential to understand how food labelling influences consumer perceptions of food risk. This distinction refers to risks based on their cause and the delimitation of hazards by their origin (natural or caused by industrialization). Food labelling serves as a symbol of the management of the traditional food system of risk, but also of the potential of modern risks. The identification that labelling can serve as a symbol to reassure and raise consumer awareness of the risks is also new. As such, it provides a much more nuanced understanding of consumer food risk frameworks and how consumers negotiate food labelling as a conduit for food supply [4]. The objective of this research was to determine the nutritional composition of the arepa with egg. Arepa with egg labelling was carried out by selecting the best treatment based on optimization studies, sensory and physical-chemical analysis; for the design, resolution 333 of 2011 was taken into account [5].

\section{MATERIALS AND Methods}

\section{A. Formulation and elaboration of the arepa with egg}

The arepas with egg were made with yellow caricaceous corn dough, pre-elaborated, Rapimasa ${ }^{\circledR}$ brand, which was provided by Inversiones MIDA S. A. S. With the dough ready, the samples were molded with the desired dimensions, for this case a circular plate of $10 \mathrm{~cm}$ in diameter and $2 \mathrm{~cm}$ thick, with two layers of dough. This was made in a suitable mould for this purpose, with a small concavity to add the egg (Fig. 1). 


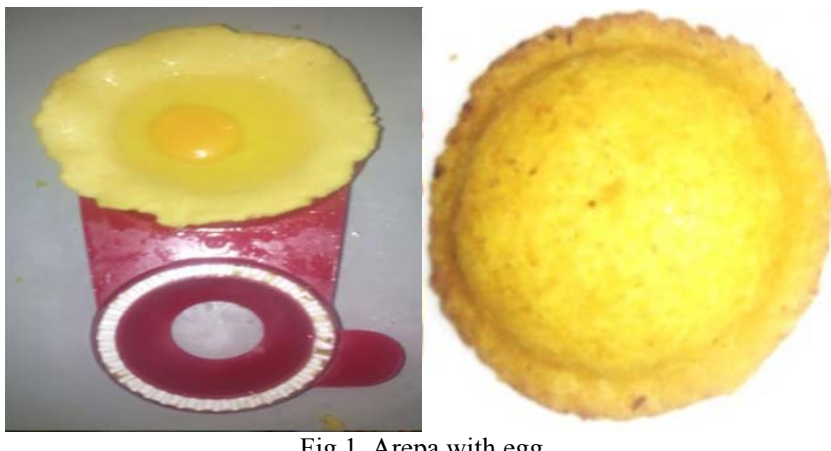

Fig 1. Arepa with egg

A mixture of sesame paste, roasted eggplant, onion, butter and dried tomatoes was used as a meat substitute. The eggplant after dehydration was finely chopped like tomatoes and onions, then sautéed in butter. These ingredients were smothered and then mixed with sesame paste. This paste was prepared with a mixture of ground beef; the sesame paste was made taking into account the technological process described by Acevedo et al., [6] in its work evaluating the rheological properties of handmade and technified sesame paste. In Table 1, the formula used to make arepas with egg is outlined.

Table 1. Formulation of the coastal arepa with egg with meat substitute.

\begin{tabular}{|c|c|c|}
\hline \multirow{2}{*}{ Ingredients } & \multicolumn{2}{|c|}{ Formulation } \\
\cline { 2 - 3 } & Amount & $\mathbf{( \% )}$ \\
\hline Yellow Corn Dough $(\mathrm{g})$ & 200 & 68.49 \\
\hline Whole Eggs Raw $(\mathrm{g})$ & 40 & 13.70 \\
\hline Ground Meat $(\mathrm{g})$ & 50 & 17.12 \\
\hline Salt & 1 & 0.34 \\
\hline Ground pepper & 1 & 0.34 \\
\hline Total & 292 & 100 \\
\hline
\end{tabular}

\section{B. Vacuum frying process}

Vacuum frying of the samples of arepas with eggs was carried out in the Gastrocac ${ }^{\circledR}$ (International Cooking Concepts, Barcelona) with measures: $40 \mathrm{~cm} \times 26 \mathrm{~cm} \times 46 \mathrm{~cm}$, maximum capacity of $10.5 \mathrm{~L}$ and $220 \mathrm{~V}$ tension. The working pressure in the frying process was $30 \mathrm{kPa}$, at which the boiling water temperature is $70^{\circ} \mathrm{C}$, was used temperature deltas of $110^{\circ} \mathrm{C}$, so the frying temperature used was $180^{\circ} \mathrm{C}$, with a fixed time of $300 \mathrm{~s}$ and $400 \mathrm{~s}$. The oil was first heated to the selected frying temperature, samples were placed in the basket, the lid closed and the vacuum pump activated. When the equipment reached the desired working pressure, the basket was lowered and immersed in hot oil. Once the frying time had elapsed, the basket was lifted, the pump was left on for one minute, the vacuum was broken and the equipment turned off, removing the samples from it. The ratio of the product/oil was 1:10, after which the arepas were drained in a basket of mesh. This process was similar to that applied by Shyu et al., [7]; Diamante et al., [8] Troncoso et al., [9]; Dueik and Bouchon, [10].

\section{Physicochemical analysis}

Analyses were performed for the determination of total fat, carbohydrates, fiber, sugars, protein, cholesterol, sodium, vitamin A, vitamin C, vitamin B2, vitamin B6, vitamin B12, vitamin E, iron, zinc, manganese, calcium, magnesium, copper, sodium, potassium.

\section{Nutritional label design}

A label was implemented for the product, which had nutritional information in accordance with Resolution 333 of 2011 [5], which establishes the technical regulation on the requirements of labeling or nutrition labelling that must comply with packaged food for human consumption.

\section{E. Experimental design}

A completely randomized design was carried out according to previous and published research, selecting the best treatments of atmospheric and vacuum frying, in order to compare the chemical composition 
(bromatological, minerals and vitamins). Data were tabulated and analyzed in Statgrapichs 16.1.15 ${ }^{\circledR}$ Version 16.0 .

\section{RESULTS AND DISCUSSIONS}

Table 2 shows the chemical composition of the fried arepa at atmospheric and vacuum conditions. There is evidence that the oil content in vacuum fried arepas reported lower fat content. It is detailed that the type of frying had no significant effect on the lipid profile, it can be inferred that the fatty acids present in the arepa with egg were provided by palm oil, egg added to the dough and sesame paste. Marcano et al., [11] determined the fatty acid content during the frying of potatoes in original olein according to the type of peeling and frying cycles.

The values of fatty acids found in the potato chips were similar to those of the frying oil, since the potato is a tuber that has an insignificant amount of fat, therefore these acids found during frying correspond to those of olein that are absorbed during frying.

Table 2. Chemical composition of the arepa with fried egg at $180^{\circ} \mathrm{C}$ and $300 \mathrm{~s}(\%)$ in $100 \mathrm{~g}$

\begin{tabular}{|c|c|c|c|c|c|c|}
\hline Parameters & $\begin{array}{c}\text { Atmospheric frying } \\
\left(180^{\circ} \mathrm{C}-300 \mathrm{~s}\right)\end{array}$ & $\begin{array}{l}\text { Atmospheric frying } \\
\left(170^{\circ} \mathrm{C}-420 \mathrm{~s}\right)\end{array}$ & $\begin{array}{l}\text { Vacuum frying } \\
\left(180^{\circ} \mathrm{C}-300 \mathrm{~s}\right)\end{array}$ & $\begin{array}{l}\text { Vacuum frying } \\
\left(170^{\circ} \mathrm{C}-420 \mathrm{~s}\right)\end{array}$ & Mean & $\begin{array}{l}\text { Standard } \\
\text { deviation }\end{array}$ \\
\hline Moisture & 38.55 & 35.46 & 39.54 & 37.54 & 37.85 & 2.13 \\
\hline Fat & 28.72 & 26.57 & 27.65 & 28.12 & 27.65 & 1.08 \\
\hline Protein & 6.53 & 6.59 & 6.62 & 6.55 & 6.58 & 0.05 \\
\hline Ash & 0.97 & 1.06 & 0.91 & 0.95 & 0.98 & 0.08 \\
\hline Crude fiber & 0.63 & 0.42 & 0.55 & 0.48 & 0.53 & 0.11 \\
\hline Carbohydrate & 24.60 & 29.90 & 24.73 & 30.13 & 26.41 & 3.02 \\
\hline $\begin{array}{c}\text { Calories (kcal } \\
\left.100 \mathrm{~g}^{-1}\right)\end{array}$ & 383.00 & 385.09 & 374.25 & 398.23 & 380.78 & 5.75 \\
\hline \multicolumn{7}{|c|}{ Minerals } \\
\hline Iron & 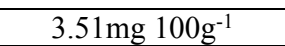 & 3.37 & 3.21 & 3.82 & 3.47 & 0.31 \\
\hline Zinc & 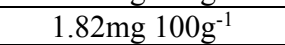 & 1.78 & 1.66 & 1.85 & 1.76 & 0.09 \\
\hline Manganese & $0.44{\mathrm{mg} 100 \mathrm{~g}^{-1}}$ & 0.37 & 0.32 & 0.39 & 0.36 & 0.03 \\
\hline Calcium & $35.55{\mathrm{mg} 100 \mathrm{~g}^{-1}}$ & 39.54 & 37.34 & 31.24 & 36.04 & 4.3 \\
\hline Magnesium & 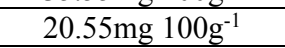 & 20.11 & 22.45 & 24.34 & 22.3 & 2.12 \\
\hline Copper & $0.12{\mathrm{mg} 100 \mathrm{~g}^{-1}}^{-1}$ & 0.08 & 0.26 & 0.15 & 0.16 & 0.09 \\
\hline Sodium & 31.95 & 33.27 & 35.65 & 31.45 & 33.45 & 2.10 \\
\hline \multicolumn{7}{|c|}{ Vitamins } \\
\hline $\begin{array}{l}\text { Vitamin A } \\
\mathrm{UI} / 100 \mathrm{~g}\end{array}$ & $<20$ & $<20$ & $<20$ & $<20$ & $<20$ & $<20$ \\
\hline $\begin{array}{l}\text { Vitamin C } \\
\mathrm{mg} / 100 \mathrm{~g}\end{array}$ & $<0.1$ & $<0.1$ & $<0.1$ & $<0.1$ & $<0.1$ & $<0.1$ \\
\hline Vitamin $\mathrm{B}_{2}$ & 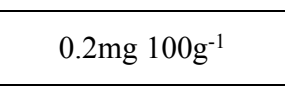 & $0.15 \mathrm{mg} 100 \mathrm{~g}^{-1}$ & 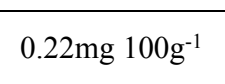 & 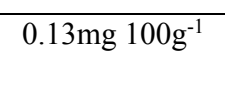 & $\begin{array}{c}0.175 \mathrm{mg} / \\
100 \mathrm{~g}\end{array}$ & $\begin{array}{c}0.042 \mathrm{mg} / \\
100 \mathrm{~g}\end{array}$ \\
\hline Vitamin $\mathrm{B}^{6}$ & $0.1 \mathrm{mg} 100 \mathrm{~g}^{-1}$ & $0.09{\mathrm{mg} 100 \mathrm{~g}^{-1}}^{2}$ & $0.12{\mathrm{mg} 100 \mathrm{~g}^{-1}}^{2}$ & $0.007 \mathrm{mg} 100 \mathrm{~g}^{-1}$ & 0.08 & 0.05 \\
\hline Vitamin $\mathrm{B}_{12}$ & 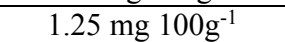 & 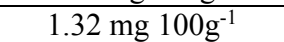 & $1.42{\mathrm{mg} 100 \mathrm{~g}^{-1}}^{2}$ & 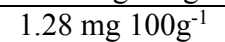 & 1.32 & 0.07 \\
\hline Vitamin E & 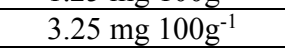 & $3.50 \mathrm{mg} 100 \mathrm{~g}^{-1}$ & $4.02 \mathrm{mg} 100 \mathrm{~g}^{-1}$ & $3.38 \mathrm{mg} 100 \mathrm{~g}^{-1}$ & 3.54 & 0.33 \\
\hline \multicolumn{7}{|c|}{ Lipid profile } \\
\hline Cholesterol & $175 \mathrm{mg} 100 \mathrm{~g}^{-1}$ & $180 \mathrm{mg} 100 \mathrm{~g}^{-1}$ & 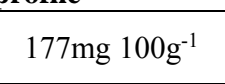 & $185 \mathrm{mg} 100 \mathrm{~g}^{-1}$ & $\begin{array}{c}179.25 \\
\mathrm{mg} 100 \mathrm{~g}^{-1}\end{array}$ & 4.35 \\
\hline C 12:0 & 0.74 & 0.78 & 0.70 & 0.67 & 0.72 & 0.05 \\
\hline C 14:0 & 1.06 & 1.12 & 0.98 & 1.08 & 1.06 & 0.05 \\
\hline C 16:0 & 35.98 & 34.22 & 30.56 & 28.32 & 32.27 & 3.46 \\
\hline C 18:0 & 3.01 & 2.98 & 2.87 & 2.91 & 2.94 & 0.06 \\
\hline C 18:1 & 46.48 & 44.22 & 45.25 & 43.25 & 44.81 & 1.38 \\
\hline
\end{tabular}

Regarding the percentage of minerals, it is observed that the results were similar between vacuum and atmospheric fried arepas, i. e. the type of process did not influence the content of these nutrients. If minerals from fried foods are analyzed, few studies are reported. Juarez et al., [1], studied the effect of Milanese frying on the content of $\mathrm{Fe}, \mathrm{Ca}, \mathrm{Mg}, \mathrm{Zn}$ and $\mathrm{Cu} ; \mathrm{Fe}, \mathrm{Ca}$ and $\mathrm{Cu}$ being the minerals that are most retained $(97 \%)$ and $\mathrm{Zn}$ was eliminated in $9.3 \%$. In a study by Gall et al., [12], they reported no changes in the mineral composition of fatty fish (mackerel) after baking or frying. In the case of low-fat fish (shrimp and red snapper), small losses of important minerals (up to 20\%) were observed, but losses after frying were very limited. Finglas and Faulks [13] compared mineral losses in potatoes after boiling, baking and frying. These losses occurred only during boiling 
and it was found that the reduction in mineral content was the result of leaching from cooking in water. Therefore, the mineral content is very little affected by fat frying in food.

There is also evidence that the vitamin intake of the arepa is significant if compared to other types of food, it should be borne in mind that the intake of these compounds is influenced mainly by the egg and sesame paste. Vitamins are organic compounds that are indispensable in very small amounts in the diet. They form a heterogeneous group of substances and are vital nutrients. They have specific and individual functions that promote growth or reproduction, or to maintain health and life. They regulate metabolic processes, control functions and prevent diseases such as ascorbate and rickets. The conventional science of nutrition divides vitamins into two categories: fat-soluble and water-soluble vitamins, which are nine. Suaterna [14], stated that the water-soluble vitamins present a high stability to frying, when compared with boiling cooking, since during frying the food does not exceed $100^{\circ} \mathrm{C}$ indoors and frying times are short, also a crust is formed that functions as a protection to prevent liquids from the matrix are removed to the heating medium. During processing and cooking conditions cause loss of vitamins, losses vary widely by cooking method and type of food [15]. Speaking of vitamin A, it is stable under an inert atmosphere; however, it quickly loses its activity when heated in the presence of oxygen, especially at higher temperatures.

Pandya and Patel [16] determined the effect of different cooking temperatures on vitamin A retention in Ghee (cleared butter). These authors reported that at higher temperatures vitamin A and carotenoids decreased proportionally. Speek et al., [17] investigated the effect of processing on carotenoid content of Thai vegetables, reporting that vitamin A losses were 14\% during cooking and 24\% during frying. Sunpuang et al., [18] studied the effects of local preparation procedures and the vitamin A content of traditional food. In general, the retinol content of cooked foods was lower than uncooked foods. For vegetables, bleaching resulted in a $7-11 \%$ loss of b-carotene, while steam, frying and boiling showed losses of $15 \%, 18 \%$ and $43 \%$ respectively. Padmavati et al., [19] observed that b-carotene losses were lower when heating was kept to a minimum, they also reported that frying resulted in a double loss compared to shallow frying.

Vitamin D is susceptible to alkaline $\mathrm{pH}$, light and heat. Vitamin D may be said to be relatively stable, however, fat content is probably the crucial factor affecting retention during culinary treatment. A high fat content usually results in a high loss of vitamin D due to dripping. Simonne and Etenmiller [20] studied vitamin E content in chicken nuggets and breaded shrimp after frying. The chicken nuggets were previously cooked during the manufacturing process. The increase in total vitamin $\mathrm{E}$ was not substantial $\left(4.6 \mathrm{mg} 100 \mathrm{~g}^{-1}\right)$ before frying and $5.1 \mathrm{mg} / 100 \mathrm{~g}$ after frying. The authors noted that the presence of tocotrienols in oils can affect the stability of retinyl palmiate by protecting against thermal oxidation. These authors observed that total vitamin $\mathrm{E}$ (tocopherols and tocotrienols) decreased rapidly in palm oil than in soybean or corn oil. Foods fried in vegetable oils are enriched with a substantial amount of vitamin E, because all vegetable oils used for frying contain

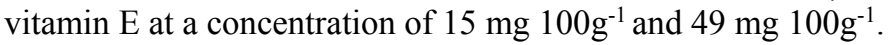

With emphasis on vitamin $\mathrm{C}$, it can be observed that it was not significant in fried arepas, because it is a compound susceptible to high temperatures. Eheart and Gott [21] reported that vitamin C retention for broccoli was higher after sauteing, as well as after cooking in a small amount of water. According to Karlström and Jonsson [22] they stated that the decrease in vitamin $\mathrm{C}$ content in potatoes depends on the amount of oxygen present during cooking. Burg and Fraile [23] pointed out that the presence of oxygen was the main cause of vitamin $\mathrm{C}$ destruction when the time spent in the oven was extended. They also noted that the destruction of this vitamin during cooking was mainly caused by enzymatic reactions and heat treatments.

On the other hand, in relation to thiamine, some researchers have indicated that it is highly unstable at alkaline $\mathrm{pH}$, the stability depends on the degree of heating and the properties of the food matrix. Al-Kahalife and Dawood [24] studied the reaction of thiamine during cooking of chicken meat, being more sensitive to heat than riboflavin. In addition, the greatest losses of thiamine occur during roasting and frying. Fillon and Henry [25] found that loss of thiamine during frying depended on the type of meat. One of the factors that most affects thiamine stability is the $\mathrm{pH}$ value of the solution. Fat content can be a factor with a positive influence on the protection of thiamine during heat treatment. The thermal degradation of vitamin B6 increases as $\mathrm{pH}$ increases. Olds et al., [26] observed that meat frying resulted in losses of this vitamin, approximately $6.5 \%$, however these authors considered it to be stable during fat frying, as it is resistant to heat and acids, but sensitive to light in neutral and alkaline solutions. 


\section{A. Design of nutritional labelling of arepa with egg}

Table 3 shows the nutritional information of the arepa with vacuum fried egg $\left(180^{\circ} \mathrm{C}-300 \mathrm{~s}\right)$. Arepa is shown to provide $66 \%$ fat of the recommended daily value, being a high amount for the population with obesity and atherosclerosis; however, fiber intake can help in the absorption of fats. The important thing is to declare all the nutritional components provided by this food, so that customers are aware of the product to be consumed. A possible solution for improving labelling strategies could be to give consumers more information in text form. However, more detailed information on the process or quality of a product may result in an overload of information for consumers [27].

\begin{tabular}{|c|c|}
\hline \multicolumn{2}{|c|}{ Nutritional Information } \\
\hline \multicolumn{2}{|l|}{ Serving Size $1(150 \mathrm{~g})$} \\
\hline \multicolumn{2}{|l|}{ Servings Per Container } \\
\hline \multicolumn{2}{|l|}{ Amount per serving (1) } \\
\hline Calories 560 & Calories from Fat 370 \\
\hline & Daily Value * \\
\hline Total Fat 41g & $63 \%$ \\
\hline Saturated fat $18 \mathrm{~g}$ & $90 \%$ \\
\hline Trans Fat $0 \mathrm{~g}$ & $0 \%$ \\
\hline Cholesterol $265 \mathrm{mg}$ & $88 \%$ \\
\hline Sodium 540mg & $22 \%$ \\
\hline Total Carbohydrate $37 \mathrm{~g}$ & $12 \%$ \\
\hline Dietary Fiber $<1 \mathrm{~g}$ & $3 \%$ \\
\hline Protein $10 \mathrm{~g}$ & $20 \%$ \\
\hline Vitamin $A<2 \%$ & Vitamin C $0 \%$ \\
\hline Calcium $\quad 6 \%$ & Iron $\quad 30 \%$ \\
\hline
\end{tabular}

Feunekes et al., [28] compared simple (like healthier) nutrition labels to more complex (like health wheel) labels. The results suggest that there are only small differences in consumer friendliness and intended use between different types of labels. Due to the lack of time in a purchasing situation, these authors recommend a simpler labelling system. This is supported by a review article by Grunert and Wills [29] where they find that consumers like the idea of having simplified information on the front of their product range.

\section{ConCLUSIONS}

Arepas with lower fat content were obtained during vacuum frying; the mineral content was not affected by the type of frying. The calorie intake was approximately 560 calories, with $66 \%$ calories from fat. Vacuum frying can be an alternative to frying arepas with better nutritional characteristics compared to atmospheric frying.

\section{REFERENCES}

[1] M. D. Juarez, M. E. Alfaro, and N. Sammán, "Nutrient retention factors of deep-fried milanesas," Journal of Food Composition and Analysis, vol. 17, no. 1, pp. 119-124, 2004.

[2] I. S. Saguy, D. Dana, "Integrated approach to deep fat frying: engineering, nutrition, health and consumer aspects", Journal of food engineering, vol. 56, no. 2, pp. 143-152, 2003.

[3] S. F. Kirk, D. Greenwood, J. E. Cade, and A. D. Pearman, "Public perception of a range of potential food risks in the United Kingdom", Appetite, vol. 38, no. 3, pp. 189-197, 2002.

[4] K. Dunno, K. Cooksey, P. Gerard, R. Thomas, and W. Whiteside, "The effects of transportation hazards on shelf life of packaged potato chips", Food Packaging and Shelf Life, vol. 8, pp. 9-13, 2016.

[5] Resolución número 333 de 2011. Ministerio de la Protección Social. Consultado en: file://C:/Users/Luis\%20Gallo/Downloads/Res 333 de feb 2011 Rotulado nutricional\%20(1).pdf (20 de julio de 2017).

[6] D. Acevedo, P. Montero y Y. Marrugo, "Evaluación de las propiedades reológicas de pastas de ajonjolí artesanal y tecnificada", Revista U.D.C.A Actualidad \& Divulgación Científica, vol. 16, no. 1, pp. 245-251, 2013.

[7] S.L. Shyu, L.B. Hau, and L.S. Hwan, "Effects of processing conditions on the quality of vacuum-fried carrot chips", Journal of the Science of Food and Agriculture, vol. 85, no. 11, pp. 1903-1908, 2005.

[8] L. M. Diamante, S. Shi, A. Hellmann, and J. Busch, "Vacuum frying foods: products, process and optimization", International Food Research Journal, vol. 22, no. 1, pp. 15-22, 2015.

[9] E. Troncoso F. Pedreschi and R. Zúñiga, "Comparative study of physical and sensory properties of pre-treated potato slices during vacuum and atmospheric frying", LWT - Food Science and Technology, vol. 42, no. 2, pp. 187-195, 2009. 
[10] V. Dueik, P. Robert, and P. Bouchon, "Vacuum frying reduces oil uptake and improves the quality parameters of carrot crisps", Food Chem, vol. 119, pp. 1143-1149, 2010.

[11] J. Marcano, Y. La Rosaa, N. Salinasa, and E. C. Venezuela, "Influencia del proceso de fritura en profundidad sobre el perfil lipídico de la grasa contenida en patatas tipo "french", empleando oleina de palma", Grasas y aceites, vol. 61, no. 1, pp. 29-24, 2010.

[12] K.L. Gall, W.S. Otwell and H. Appledorf, "Effects of four cooking methods on the proximate, mineral and fatty acid composition of fish fillets", J. Food Sci., vol. 48, no. 4, pp. 1068-1074, 1983.

[13] P.M. Finglas and R.M. Faulks, "Nutritional composition of UK retail potatoes, both raw and cooked", J. Sci. Food Agric., vol. 35, no. 12, pp. 1347-1356, 1984.

[14] A.C. Suaterna, "La fritura de los alimentos: el aceite de fritura", Perspectivas en nutrición humana, vol. 11, no. 1, pp. 39-53, 2011.

[15] E. Lešková, J. Kubíková, E. Kováčiková, M. Košická, J. Porubská, and K. Holčíková, "Vitamin losses: Retention during heat treatment and continual changes expressed by mathematical models", Journal of Food Composition and analysis, vol. 19, no. 4, pp. 252-276, 2006.

[16] M.P. Pandya, and B.M. Patel, "Effect of cooking temperatures on vitamin A potency of ghee", Journal of the Institution of Chemists (India), vol. 44, no. 5, pp. 160-162, 1972.

[17] A.J. Speek, S. Speek-Saichua, W.H.P. Schreurs, "Total carotenoid and b-carotene content of Thai vegetables and effect of processing", Food Chemistry, vol. 27, pp. 245-257, 1988.

[18] P. Sungpuag, S. Tangchitpianvit, U. Chittchang, U. Wasantwisut, "Retinol and b-carotene content of indigenous raw and homeprepared foods in Northeast Thailand", Food Chemistry, vol. 64, pp. 163-167, 1999.

[19] K. Padmavati, S.A. Udipi, M. Rao, "Effect of different cooking methods on b-carotene content of vegetables", Journal of Food Science and Technology-Mysore, vol. 29, no. 3, pp. 137-140, 1992.

[20] A.H. Simonne, R.R. Eitenmiller, "Retention of vitamin $\mathrm{E}$ and added retinyl palmitate in selected vegetable oils during deep-fat frying and fried breaded products", Journal of Agricultural and Food Chemistry, vol. 46, pp. 5273-5277, 1998.

[21] M.S. Eheart, and C. Gott, "Chlorophyll, ascorbic acid and pH changes in green vegetables cooked by stir fry, microwave, and conventional methods and a comparison of chlorophyll methods", Food Technology, vol. 19, no. 5, pp. 186-188, 1965.

[22] B. Karlström, and L., Jonsson, "Warm-Holding of Potatoes in Different Equipment", SIK, Göteborg, Sweden, 1980.

[23] P. Burg, and P. Fraile, "Vitamin C destruction during the cooking of potato dish", Lebensmittel Wissenschaft und Technologie vol. 28, no. 5, pp. 506-514, 1995.

[24] A.S. Al-Khalifa, and A.A. Dawood, "Effects of cooking methods on thiamin and riboflavin contents of chicken meat", Food Chemistry, vol. 48, no. 1, pp. 69-74, 1993.

[25] L. Fillion, and C.J.K. Henry, "Nutrient losses and gains during frying: a review", International Journal of Food Sciences and Nutrition, vol. 49 , pp. $157-168,1998$.

[26] S.J. Olds, J.T. Vanderslice, D. Brochetti, "Vitamin B6 in raw and fried chicken by HPLC", Journal of Food Science, vol. 58, no. 3, pp. 505-507, 1993.

[27] J. Kolodinsky, "Persistence of health labeling information asymmetry in the United States: Historical perspectives and twenty-first century realities", Journal of macromarketing, vol. 32, no. 2, pp. 193-207, 2012.

[28] G. I. Feunekes, I. A. Gortemaker, A. A. Willems, R. Lion, and M. Van Den Kommer, "Front-of-pack nutrition labelling: testing effectiveness of different nutrition labelling formats front-of-pack in four European countries", Appetite, vol. 50, no. 1, pp. 57-70, 2008)

[29] K. G. Grunert and J. M. Wills, "A review of European research on consumer response to nutrition information on food labels", Journal of public health, vol. 15 , no. 5, pp. 385-399, 2007. 